\title{
Phenotyping cowpeas for adaptation to drought
}

\author{
Anthony E. Hall * \\ Department of Botany and Plant Sciences, University of California, Riverside, CA, USA
}

Edited by:

Jean-Marcel Ribaut, Generation Challenge Programme, Mexico

Reviewed by:

Uener Kolukisaoglu, University of

Tuebingen, Germany

Vasileios Fotopoulos, Cyprus

University of Technology, Cyprus

*Correspondence:

Anthony E. Hall, Department of

Botany and Plant Sciences, University of California, 2922 Lindsay Lane,

Quincy, Riverside, CA 95971, USA.

e-mail: anthony.hall@ucr.edu
Methods for phenotyping cowpeas for adaptation to drought are reviewed. Key factors involve achieving optimal time of flowering and cycle length, and appropriate morphology for different types of cultivars as they relate to their utilization for dry grain, hay, and fresh pea production. Strong resistance to vegetative-stage drought is available and should be incorporated. The extreme ability of extra-early erect cowpea cultivars to escape terminal drought should be exploited in zones with very short rainfall seasons. In zones with the possibility of limited rainfall in the middle of the growing season, resistance to mid-season drought, and the delayed-leaf-senescence trait can be valuable. Breeding for water-use efficiency, deeper rooting, and heat tolerance are discussed. Diseases and pests that influence adaptation to drought are considered. Resistance to the organism causing ashy stem blight disease should be incorporated because this disease can destroy cowpea seedlings under hot, dry soil conditions. The value of varietal intercrops with contrasting types of cowpea cultivars in enhancing adaptation to drought is described. Implications of cowpea/cereal rotations for cowpea breeding are discussed. Breeding strategies for enhancing cowpea adaptation to drought are described.

Keywords: cowpeas, drought resistance, drought adaptation, water-use efficiency, heat tolerance, leaf electrolyte leakage

\section{INTRODUCTION}

\section{USES OF COWPEAS FOR FOOD AND FEED AS THEY RELATE TO CULTIVAR TYPES AND DROUGHT ADAPTATION}

The various uses of cowpeas (Vigna unguiculata L. Walp.) as food and as feed for animals influence the types of cultivar that are needed. The developmental and morphological traits associated with these uses also influence the adaptation of the cultivars to drought. The main use of cowpeas as a food is as dry grains which have more resistance to terminal drought than either fresh peas or immature pods.

Cowpea grains have substantial quantities of protein (about $25 \%$ ) and carbohydrate (about 64\%), vitamins, and fiber. The amino acid and vitamin profiles of cowpea grain complement those of cereals. When one part of cowpea grain is combined with three parts of cereal grain it provides a near-complete food. In the subsistence farming areas where it mainly is grown, the main role of cowpeas is as a concentrated source of protein that is cheaper than fish, meat, poultry, or dairy products and combines well with cereal grains in the human diet.

In some cases, the pods of cowpeas are harvested when they are full sized and before they dry out. The pods are then shelled and the grains are cooked and eaten as fresh "southern peas." This practice has been important in the southeastern United States. Since 1985 the consumption of cowpeas as fresh southern peas has also become important in the semi-arid Sahelian zone of Africa in Senegal. The reason for this is that, with the introduction of extraearly cowpea varieties, southern peas became available during the "hungry period" of August and September. This period is just before the main harvests of pearl millet, sorghum, and dry grains of traditional varieties of cowpeas and peanuts, which begin in
October. Estimates made in Senegal from 1994 to 1996 indicated that fresh southern peas commanded a price twice that of dry grains on a per seed basis. Marketing of fresh southern peas brings in much-needed cash during the hungry period and is done mainly by women. Estimates in the early 2000s indicated that about $30 \%$ of cowpea grains were consumed as fresh southern peas in Senegal. Substantial quantities of cowpeas were also being consumed as either fresh southern peas or immature pods in Niger. Consumption of cowpeas as fresh southern peas is probably increasing in the Sahelian zone as extra-early cowpea cultivars are being made available to farmers.

Immature pods of cowpea cultivars are consumed fresh in Kenya (African green beans), Trinidad (bodie beans), and Southeast Asia (yard-long beans). Bush-type cultivars with succulent pods bred for this particular use are available. The fresh leaves of cowpeas are consumed in sauces, especially in East Africa.

A major use of cowpeas in the Sahelian zone of Africa is as hay, after the pods have been harvested. Hay is particularly important in Niger where it had a cash value to farmers of about half of that of the grain in the 1990s. Hay is used to maintain draft animals during the long dry season in the Sahel and to fatten rams and goats in preparation for various festivals.

Cowpeas are particularly important as a rotation crop with cereals. They can enhance the fertility of the soil with respect to nitrogen and phosphate, thereby benefiting subsequent cereal crops. Certain cowpea lines can cause suicidal germination of the seeds of Striga hermonthica, which parasitizes pearl millet, sorghum, and maize. Certain lines can also suppress the populations of the nematode Scutellonema cavenessi, which is a major pest of pearl millet, sorghum, and peanut in the Sahel. Two successive 
crops of pearl millet (Sauna III cultivar) can suppress the organism responsible for the ashy stem blight disease (Macrophomina phaseolina) that can attack cowpea seedlings growing in hot dry soils. These potential benefits of rotational systems involving sole crops of cowpeas, sole crops of cereal, and sole crops of other species, such as peanuts, have not been adequately quantified. In Africa, cowpeas are still often grown as an intercrop with cereals, although they are mainly grown as a sole crop in Senegal.

The guidelines for breeding cowpeas for adaptation to drought provided below are based on the assumption that, in the future, most cowpeas in the world will be grown as a sole crop in rotation with sole crops of cereals and some other species. The traits described that confer adaptation to drought in cowpeas as a sole crop, also are effective when cowpeas are grown as a component of a species intercrop.

\section{CULTIVATED AREA AND YIELD PERFORMANCE UNDER OPTIMAL CONDITIONS}

The cultivated area of cowpeas world-wide was estimated as being 14 million ha in 2000 (Singh et al., 2002) with the most production being in Africa in the Sudanian Savanna zone (especially in northern Nigeria) and the Sahelian zone (especially in southern Niger, central Mali, the Sudan, and Senegal). In addition, there was significant production in northeastern Brazil, eastern and southern Africa, and Southeast Asia. Most of the areas where cowpeas are grown are semi-arid, and often experience droughts ranging from being severe in the Sahelian zone to being moderate in the Sudanian Savanna zone, northeastern Brazil and East Africa during the long rainy season.

Average grain yields in 1999-2000 (in $\mathrm{kg} \mathrm{ha}^{-1}$ ) were 417 in Nigeria, 171 in Niger, 324 in Brazil, 220 in Mali, and 362 in Senegal. There is considerable opportunity to increase these yields. For example, under optimal conditions, cowpeas have produced $3,000 \mathrm{~kg} \mathrm{ha}^{-1}$ in Senegal. Yield under optimal conditions can be estimated effectively for different cultivars and parts of the world by using a model. Grain yield of cowpeas in optimal conditions (Y) has been modeled by Hall (1999) using the following equation:

$$
Y=\sum_{i=n}^{i=0} \operatorname{PPFD}_{i} \cdot \mathrm{GC}_{i} \cdot \mathrm{Q}_{i} \cdot \mathrm{PG}_{i}
$$

where PPFD is the flux density of photosynthetically active photons per day, GC is the ratio of plant cover to ground area on that day, $Q$ is the efficiency for the conversion of intercepted photons to plant dry biomass, and PG is the ratio for the partitioning of plant biomass to grain. This equation applies over the period of days $(n)$ when carbohydrate is being partitioned to grain. The number of days from the beginning of flowering to the time when $95 \%$ of the pods are mature provides an estimate of the value of $n$.

Examples of the use of this model are provided below based on measurements made in California and Senegal (Hall, 1999). The length of the reproductive period for cultivars growing in California was 50 days for the first flush of flowering and pod production. Due to long 15-h days and sunny conditions, PPFD can be as much

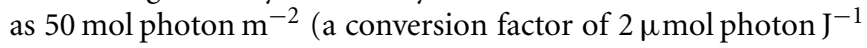
can be used if the only data available are for daily solar irradiance).
Under optimal conditions, GC should be close to 1.0. In California $Q$ values for cowpeas of $450 \mathrm{mg}$ dry matter mol photon ${ }^{-1}$ have been obtained. Under optimal conditions values for partitioning would be slightly less than the optimal apparent harvest index (HI; the ratio of grain yield to total shoot biomass at harvest), say, about 0.444 . Putting these values into the model predicts that, with long sunny days, cowpeas can accumulate about $1,000 \mathrm{~kg} \mathrm{ha}^{-1}$ of grain in 10 days. This would predict that during a 50-day period of grain filling under these optimal conditions, cowpeas could produce $5,000 \mathrm{~kg} \mathrm{ha}^{-1}$. Yields of this magnitude have been observed in large plot and large field conditions in California for crops that began flowering in 50 days and reached maturity in 100 days from sowing, although yields of $4,000 \mathrm{~kg} \mathrm{ha}^{-1}$ are more common (Ehlers et al., 2000).

In Senegal, under tropical conditions with higher temperatures, these Californian cultivars develop faster and have a reproductive duration for the first flush of pods of only 25 days, the PPFD is less than 50 mol photon $\mathrm{m}^{-2}$ due to shorter days and cloudiness, and their grain yields were only $2,400 \mathrm{~kg} \mathrm{ha}^{-1}$ (Hall and Patel, 1985). A cultivar that is well adapted to Senegal, "Mouride," has produced grain yields as high as $3,000 \mathrm{~kg} \mathrm{ha}^{-1}$ and has a reproductive duration of about 35 days. These performances are approximately consistent with the model. The take-home message is that the yield potential of cowpeas is determined by the length of the reproductive period, which depends on the cultivar and temperature, the amount of sunlight during this period, which depends upon on the length of the day, the degree of cloudiness and the position of the sun in the sky, and the extent of production and partitioning of carbohydrate to grain.

\section{GENETIC AND GENOMIC RESOURCES}

In the early 2000s, the major cowpea germplasm collections were maintained by the International Institute of Tropical Agriculture (IITA; with 14,000 accessions), the United States Department of Agriculture (USDA; with 8,000 accessions), and the University of California, Riverside (UC-Riverside; with 5,000 accessions). The Istituto di Genetica Vegetale in Bari, Italy, held a collection of Mediterranean and African landraces (about 600 accessions). Several national programs in Africa (including Botswana, Burkina Faso, Ghana, Kenya, Nigeria, and Senegal), and the national programs in Brazil and India had substantial cowpea germplasm collections. In addition, IITA and the Botanical Research Institute in Pretoria, South Africa stored seeds of some wild relatives of cowpeas.

Ouédraogo et al. (2002) have developed a genetic linkage map for cowpeas that provides a basis for initiating markerassisted selection (MAS). Further discussion of cowpea genetic and genomic resources can be found in Timko et al. (2007).

\section{RESEARCH RELEVANT TO BREEDING COWPEAS FOR DRY, HOT ENVIRONMENTS RESISTANCE TO VEGETATIVE-STAGE DROUGHT}

Cowpeas were shown to have substantial resistance to vegetativestage drought in California (Turk et al., 1980). In one treatment, seeds were sown into a dry soil profile with just enough water to permit germination and emergence. Plants survived for 43 days under very hot dry summer conditions with no rain but were 
badly stunted. Most other crop plants would have been killed with this treatment. The stunted plants were irrigated on the 44th day and recovered rapidly, producing very high grain yields of $4,000 \mathrm{~kg} \mathrm{ha}^{-1}$ by 107 days after sowing. A control treatment that had received optimal irrigations every week produced a similar grain yield during the same period. Subsequently, cowpeas have been observed to survive vegetative-stage droughts in the Sahelian zone that killed pearl millet and peanut plants growing in the same field (Hall, unpublished observations).

Survival of vegetative-stage droughts by cowpeas was associated with the maintenance of higher leaf water status than pearl millet (Petrie and Hall, 1992a,b,c). Cowpeas are fairly unique among crop plants in exhibiting very small changes in leaf water potential when subjected to drought and very little osmotic adjustment (Shackel and Hall, 1983). Cowpeas also have stomata that are very sensitive to soil drying, partially closing before any changes in leaf water potential were detected (Bates and Hall, 1981). When cowpea plants are subjected to drought in field conditions, their leaves do not usually wilt but tend to orient more vertically, tracking the sun in a manner that minimizes the interception of solar radiation (Shackel and Hall, 1979). These mechanisms contribute to the unique ability of cowpeas to survive extreme vegetative-stage droughts that kill most other crop plants.

A screening technique for survival of drought at the seedlingstage has been developed that uses a shallow soil layer in boxes (Singh and Matsui, 2002). When 190 diverse cowpea breeding lines from IITA were screened with this technique, only $22 \%$ were found to be susceptible to drought. This suggests that most current cowpea cultivars may have resistance to vegetative-stage drought. Inheritance studies indicated that the susceptibility was due to a single recessive gene. In another screening test it was shown that resistant cowpeas survived seedling-stage drought longer than all other species tested: lablab beans, bambara groundnuts, peanuts, pearl millet, sorghum, greengram, blackgram, maize, and soybeans.

There are two conditions where the resistance of cowpeas to vegetative-stage drought is not effective. First, when the organism causing the ashy stem blight disease (M. phaseolina) is present in the soil, resistance of cowpeas to vegetative-stage drought breaks down and the plants die. This disease organism is widespread and causes severe damage to cowpea seedlings growing in the hot, dry soil conditions that often occur in the Sahelian zone and in Botswana. Strong resistance to this disease was recently detected in cowpea germplasm (Ehlers, unpublished observations). Second, the lesser corn stalk borer (Elasmopalpus lignosellus) has attacked and killed young cowpea plants that were subjected to drought while plants in well-watered treatments were not killed. Varietal resistance to this pest is not yet available.

\section{ESCAPING TERMINAL DROUGHT BY USING EXTRA-EARLY ERECT COWPEAS}

Since1968, many years of droughts have occurred in the Sahelian zone, resulting in very short growing seasons. In response to this problem UC-Riverside and the Institut Sénégalais de Recherches Agricoles (ISRA) bred extra-early cowpea cultivars that had very short growth cycles. The ideotype involved combining vegetative-stage drought resistance with erect plant habit and early synchronous flowering beginning on low nodes on the main stem. These cultivars do not cover much ground during the vegetativestage, and should be planted at close spacing $(50 \mathrm{~cm}$ between rows and $25 \mathrm{~cm}$ between seeds). Close spacing also enhances the synchrony of pod production and earliness of harvest.

UC-Riverside bred the cultivar "Ein El Gazal" by crossing an erect early California cultivar that had resistance to vegetativestage drought and an erect early line from Senegal bred by Djibril Sène. Lines were selected in California that had even earlier flowering than the parents. These lines were tested in the Sahelian zone at Louga, Senegal, in 1982. Line "UCR 1- 12-3" (subsequently called "Ein El Gazal") began flowering in 35 days and produced $1,091 \mathrm{~kg} \mathrm{ha}^{-1}$ of dry grain by 55 days from sowing with a useful rainfall of only $181 \mathrm{~mm}$ and very hot conditions throughout the short season (Hall and Patel, 1985). Other crops grown in the Louga area in 1982, pearl millet, peanuts, and traditional cowpeas which had 90-day cycles, produced virtually no grain. In the same year at a wetter location (Bambey, Senegal, with $452 \mathrm{~mm}$ rain), "Ein El Gazal" produced 2,406 $\mathrm{kg} \mathrm{ha}^{-1}$ of dry grain by 60 days from sowing (Hall and Patel, 1985) indicating it had high yield potential. It also performed well in the Sahelian zone of the Sudan (Hall and Patel, 1985) where it was released as a cultivar (Elawad and Hall, 2002). An extra-early erect cultivar bred in Senegal by ISRA, "Melakh," has resistance to two seed-borne diseases and cowpea aphid, and partial resistance to flower thrip. "Melakh" was released in Senegal in 1996 (Cisse et al., 1997). An early erect cultivar that matures in 60-65 days, "Vuli-1," was bred for cultivation during the short rains in Tanzania (Mligo and Singh, 2007).

"Ein El Gazal" and "Melakh" have three advantages: (i) they can survive vegetative-stage droughts; (ii) they can produce significant grain in locations and years when the rainy season is very short and all other crops produce little grain; and (iii) they produce fresh southern peas beginning about 45 days from sowing, which is during the hungry period in the Sahel. However, these extra-early erect cowpea cultivars have three disadvantages: (i) they must be sown at close spacing, which is not a major problem in Senegal where horse-drawn seeders are used; (ii) they produce very little hay; and (iii) they can be devastated by a mid-season drought (Thiaw et al., 1993) and some biotic stresses.

\section{RESISTANCE TO MID-SEASON DROUGHT}

Several approaches have been taken in breeding cowpea cultivars with greater resistance to mid-season drought than the extra-early erect cultivars. Line " $58-57$ ” was selected from a landrace growing around the Senegal River by Sène (1966). Among landraces it has a relatively short cycle, beginning flowering 41 days after sowing and reaching maturity in 75 days. It has a spreading habit and experiences sequential flowering, which may partially account for its resistance to mid-season drought. " $58-57$ ” is dual-purpose in that it can produce significant hay as well as grain. It should be sown at moderate spacing, such as with $50 \mathrm{~cm}$ between rows and $50 \mathrm{~cm}$ between seeds in the row.

"Mouride" was bred by ISRA by crossing " $58-57$ " with an erect breeding line and was released in Senegal in 1992 (Cisse et al., 1995). It is semi-erect, and under well-watered conditions reaches maturity 65 days after sowing. It has substantial yield potential, having produced $3,000 \mathrm{~kg} \mathrm{ha}^{-1}$ at Bambey, Senegal, and has 
considerable ability to resist mid-season drought. The basis for this resistance is not known. "Mouride" also has resistance to two seed-borne diseases, the plant parasitic weed Striga gesnerioides and cowpea weevil. It should be sown at close spacing, such as with $50 \mathrm{~cm}$ between rows and $25 \mathrm{~cm}$ between seeds in the row.

Reproductive activity in cowpeas can involve two separate flushes of flowering with a period of about 1 week in between when no flowers are produced. Grain yield from the second flush strongly depends on the extent of plant death due to soil pathogens after the first flush of flowering and pod production is completed. A delayed-leaf-senescence (DLS) trait has been discovered that enables cowpeas to maintain a green canopy after the first flush of pods is mature and more consistently produce a second flush of flowers and pods (Gwathmey et al., 1992a). When genotypes with this trait were subjected to a mid-season drought during the first flowering period, they had the ability to survive and then produce a substantial second flush of pods and grain (Gwathmey and Hall, 1992). Early erect lines with the DLS trait were bred, selected and tested in Senegal. Under well-watered conditions they produced a first flush of $2,000 \mathrm{~kg} \mathrm{ha}^{-1}$ of grain in about 65 days from sowing and then a second flush producing an additional $1,000 \mathrm{~kg} \mathrm{ha}^{-1}$ of grain by 95 days from sowing (Hall et al., 1997). Cultivars with both earliness and the DLS trait may be most useful in the Sudanian Savanna, which usually has a longer rainy season than the Sahelian zone but occasional mid-season droughts.

The mechanism of the DLS trait is complex. It results in the accumulation of greater reserves of carbohydrates in the base of the stem (Gwathmey et al., 1992b) and probably also in the roots. The trait is most strongly expressed when an organism that causes the senescence of cowpeas during pod maturation is present in the soil. This organism is probably Fusarium solani f. sp. phaseoli. Presumably, roots with greater carbohydrate reserves are more resistant to this root rotting organism. Irrespective of the complexity of the trait, it has been consistently expressed by plants in soils where cowpeas have been grown in rotations for several years in many locations in California and also at Bambey in Senegal. The DLS trait can be selected effectively with advanced lines in appropriate field nurseries, and appears to have simple inheritance (Ismail et al., 2000).

Dual-purpose cowpea cultivars have been bred by B. B. Singh of IITA for use in the Sudanian Savanna zone (Dingkhun et al., 2006). These cultivars are semi-erect, and reach maturity in 8595 days. They can produce $1,500-2,500 \mathrm{~kg} \mathrm{ha}^{-1}$ grain and 3,000$5,000 \mathrm{~kg} \mathrm{ha}^{-1}$ of hay when sown at moderately close spacing. The high hay production was associated with the ability to continue producing leaves after the grain had matured. Presumably these cultivars have the DLS trait.

\section{VALUE OF VARIETAL INTERCROPS}

Rainfall in the Sahelian zone has been so variable and droughts have been so extreme that a single type of cowpea cultivar may not adequately meet all of the needs of farmers. Consequently, it has been recommended that at least two types of cultivar be bred, and that farmers grow at least two types every year to enhance the chances that significant grain and hay production will be achieved every year (Hall, 2004a). The extra-early erect cultivars that have synchronous flowering and mature within 60 days from sowing, such as "Ein El Gazal," escape late-season drought and also have resistance to vegetative-stage drought. They provide useful food during the hungry period but are devastated by mid-season drought and also produce little hay. Spreading cultivars with sequential flowering and a medium-cycle maturing in 75 days, such as “58-57," have substantial resistance to mid-season drought and vegetative-stage drought. They produce useful quantities of both grain and hay, unless the growing season is very short, in which case they produce little grain. Also, they produce little grain during the hungry period. The most effective way for farmers to grow both types of cultivar may be in alternating rows as a varietal intercrop.

A comparison was made of varietal intercrops consisting of alternating rows of extra-early erect cultivars and medium-cycle spreading cultivars with sole crops of the same cultivars in the Sahelian zone of Senegal (Thiaw et al., 1993). The varietal intercrops produced more grain and hay under dry conditions with infertile soil, and were more stable than any of the sole crops of cowpeas that were tested. Some mechanisms for the beneficial effects of these varietal intercrops are as follows. In years when a mid-season drought occurs, the extra-early erect cultivar becomes stunted and the medium-cycle spreading cultivar compensates by growing into the space that is made available and produces much of the grain and hay yields of the intercrop. In years with a distinct, short rainy season, the extra-early erect cultivar produces abundant grain, while the medium-cycle spreading cultivar produces abundant hay for the intercrop but little grain. Farmers in the Sahel typically grow several cowpea cultivars but the author is not aware of any that have adopted the varietal intercrop system.

Cowpeas grown in a varietal intercrop would be rotated with sole crops of pearl millet and peanuts. For example, a 4-year rotation may be effective in parts of the Sahel in which cowpeas are followed by pearl millet, then peanuts, and then pearl millet. Thus, four equal-sized fields with staggered rotations would devote $50 \%$ of the land to producing pearl millet, the staple food crop, $25 \%$ to cowpeas, and $25 \%$ to peanuts.

\section{WATER-USE EFFICIENCY}

Increasing water-use efficiency (WUE), i.e., biomass production/crop water-use, has been proposed as a mechanism to enhance the adaptation of crops to drought. By measuring the stable carbon isotope composition of cowpea tissues, genotypic differences in transpiration efficiency (TE), i.e., photosynthetic rate/transpiration rate that were associated with genotypic differences in WUE have been detected (Ismail and Hall, 1992; Hall et al., 1994a). However, genetic selection experiments showed negative genetic correlations between grain yield and TE (and therefore WUE) for cowpeas growing under either well-watered or waterlimited stored soil moisture conditions (Condon and Hall, 1997; Hall et al., 1997). These results may, in part, be explained by: (i) the negative genetic correlations that were observed between $\mathrm{HI}$ and TE; and (ii) the possibility that more open stomata are responsible for the decreases in TE and are resulting in enhanced photosynthesis and biomass production. In the water-limited environment, the lines with decreased TE but greater grain yields may also have had deeper rooting and greater soil water extraction. 
Using selection for stable carbon isotope composition of plant tissues to decrease TE in cowpeas may provide a means to enhance grain yield under irrigated conditions in California. But there is no clear evidence that this approach would enhance drought adaptation in the Sahelian zone. TE was negatively correlated with grain yield for cowpeas grown on stored soil moisture in a subtropical zone in California. However, when a common set of cowpea genotypes was grown in California and in the tropical Sahelian zone of Senegal, there was no consistency in genotypic ranking for stable carbon isotope composition across these zones (Hall et al., 1994b). In Senegal there was a tendency for well adapted local cultivars to have carbon isotope compositions indicative of low TE.

\section{DEEPER ROOTING}

Adaptation to drought may be enhanced by breeding cowpeas with deeper rooting for a target production zone (TPZ) where the crop is grown under limited rainfall with substantial water available deep in the soil. A method has been developed for selecting stable lines of cowpeas for differences in rate of rooting (Robertson et al., 1985). The method consists of injecting a band of herbicide deep in the soil, sowing cowpea lines in row sections above the herbicide band, and scoring plants daily for the first sign of leaf herbicide symptoms as an indication that the roots had reached the herbicide band. In a separate experiment, genotypes that had showed herbicide symptoms earlier extracted more soil moisture deep in the profile. This method for detecting genotypic differences in rooting also has been shown to be effective in peanuts in Senegal (Khalfaoui and Havard, 1993). It is only effective with stable lines because the herbicide kills the plants.

The relatively small area of cowpeas grown in the Sahel during the dry season on deep alluvial soil next to rivers (the "décrue" system) might benefit from deeper rooting. The only water available to these plants is present in the soil at sowing. A breeding program for this environment might use the herbicide system to indirectly select for deeper rooting. Alternatively, a simpler indirect system could be used in which plants are sown at wide spacing $(100 \mathrm{~cm} \times 100 \mathrm{~cm})$ in the fully moistened deep alluvial soil during the dry season, and then selected based upon the extent of total shoot biomass production. Presumably, genotypes that developed deeper, more effective root systems would also produce more shoot biomass.

Deeper roots may not be advantageous for the major area of cowpea production during the rainy season on the widespread sandy soils in the Sahel. Soil water depletion data have indicated that current cultivars can develop root systems as deep as $200 \mathrm{~cm}$ under these conditions. Cultivars that developed even deeper roots would not gain much additional water from these sandy soils where the field capacity is only about $8 \%$, and only a few percentage points of soil water are available. Larger root systems have an additional cost to the plant, in terms of the carbohydrate and energy required for their construction and maintenance, a cost that must be more than repaid if the additional roots are to be of benefit to plant adaptation.

\section{HEAT TOLERANCE}

The semi-arid zones where a large area of cowpeas is grown also are hot. In subtropical areas with long days, it has been shown that high temperatures late at night disturb flower production and pollination, causing reductions in pod production (Hall, 2004b). Methods for breeding heat-tolerant cowpeas have been developed (Hall, 1992), involving selection for flower production and high pod set under hot night temperatures and long-day field or glasshouse conditions. These methods were used to breed a heattolerant cowpea cultivar for use in California (Ehlers et al., 2000). In addition, crosses were made between heat-tolerant lines developed in California and cultivars used in Ghana by K. O. Marfo. Lines were selected for heat tolerance in California and for other traits in Ghana. Two of the lines were released as cultivars in Ghana from this program (Padi et al., 2004a,b).

However, the value of the heat tolerance genes in tropical zones of Africa has not been established. Studies with pairs of lines with and without the heat tolerance genes showed the genes to be effective in California (Ismail and Hall, 1998) but of no benefit in Ghana and Senegal (Hall et al., 2002). The main reason for the latter result may be that the heat tolerance genes are much more effective under the long-day conditions that occur during the growing season in California, than under the shorter days that occur during the growing season in Ghana and Senegal (Ehlers and Hall, 1998). Another possible reason is that to be effective in tropical zones of Africa, the heat tolerance genes must be combined with other compatible genes. For example, some of the heat-tolerant lines bred in California produced many pods in Senegal but the pods did not develop due to biotic stresses.

A method has been developed that may be useful for selecting for heat tolerance under either short- or long-day conditions (Thiaw and Hall, 2004). Lines selected for low leaf electrolyte leakage under heat stress also had reproductive-stage heat tolerance. In addition, lines selected for reproductive-stage heat tolerance in long-day field conditions also had low leaf electrolyte leakage under heat stress. The leaf electrolyte leakage test can be conducted in a laboratory, with relatively simple equipment, using leaves from plants growing in field nurseries. However, it has not yet been determined whether this method can be used to select under shortday tropical conditions for plants that also exhibit heat tolerance during reproductive development under hot short-day tropical conditions.

In addition, incorporating heat tolerance during reproductive development was shown to result in a semi-dwarf habit (Ismail and Hall, 1998). While a semi-dwarf habit may be useful under intensive irrigated production in subtropical areas such as California (Ismail and Hall, 2000), it is not suitable for use under harsh rainfed conditions in semi-arid tropical environments where the expression of dwarfing is more extreme due to the more rapid plant development that occurs at higher temperatures. It has not been determined whether the association between the heat tolerance effects and dwarfing can be separated, or whether it is a pleiotropic effect of the same set of genes. Consequently, while the value of breeding for reproductive-stage heat tolerance has been established for cowpeas in subtropical long-day conditions, its value for tropical short-day environments is not clear.

\section{BIOLOGICAL NITROGEN FIXATION}

Usually, cowpeas are nodulated effectively when growing in field conditions. The author is not aware of a well-documented case 
where cowpeas have responded to seed inoculation with Rhizobia spp. under field conditions in California (Hall and Frate, 1996) or elsewhere. State-wide average yields of cowpeas in California are high (they were $2,900 \mathrm{~kg} \mathrm{ha}^{-1}$ in 1995), yet virtually no yield responses to nitrogen fertilization have been reported (Hall and Frate, 1996).

The negligible or small responses of cowpeas to soil fertilization with nitrogen may be due to its substantial biological nitrogen fixation, as has been observed in California (Elowad and Hall, 1987; Elowad et al., 1987) and Senegal (Mamadou Ndiaye, unpublished work of ISRA in the 1980s). Drought can substantially reduce biological fixation of cowpeas and cause plants to rely more on assimilated inorganic nitrogen (Elowad and Hall, 1987). This indicates that, for cowpeas, biological nitrogen fixation may be more sensitive to drought than is photosynthesis. However, this constraint does not appear to be large enough in cowpeas to justify the massive upstream plant breeding program that would likely be needed to enhance cowpea contributions to biological nitrogen fixation under drought.

\section{METHODS FOR BREEDING COWPEAS FOR ADAPTATION TO DROUGHT \\ BREEDING STRATEGIES}

A key first step is to determine the earliness of flowering, cycle length, and type of plant habit that are required in the TPZ for which the breeding program is responsible.

Optimal cycle lengths can be determined for cowpeas growing under rainfed conditions in semi-arid zones by using a hydrologic budget analysis. An effective way to do this has been described by Dancette and Hall (1979). With this method, a substantial set of rainfall data is needed for the TPZ covering at least 50 years. Also, estimates are needed of cowpea crop water-use coefficients, such as the values in Hall and Dancette (1978), and rooting depths, potential evapotranspiration, and the field capacity and lower limit of water availability in the soil. Hydrologic budgets are then determined for each of the 50-years of rainfall data to determine the maximum cowpea cycle length that would have been supported by providing the crop with at least $75 \%$ of its water requirement in that year. The 50 cycle lengths obtained for the 50 -years of data are then examined, and the maximum cycle length that was predicted to be achieved in 40 out of the 50 -years is chosen - this is the optimal cycle length for the TPZ. Cultivars with this cycle length are predicted to receive at least $75 \%$ of their maximal water requirements in 40 out of 50 years but suffer terminal drought of varying intensities in 10 of the years.

If the optimal cycle length is less than 75 days, then it will probably be necessary to develop a cultivar with synchronous flowering, which means it must be erect and sown at close spacing, and be early flowering to provide a reproductive period of adequate length. This type of cultivar would also be developed if the objective is to provide food during the hungry period, even in locations where rainfall supports a longer optimal cycle length. If the optimal cycle length is greater than 75 days, then more choices are possible, including the use of photoperiod-sensitive types for cases where the optimal cycle is longer than about 90 days. For grain production, erect types should be considered. For dualpurpose grain/hay types, either spreading types or semi-erect types with delayed-leaf-senescence (DLS) could be sought. For hay production, spreading types would be most consistent with the crop management methods currently being used in the Sahelian zone, such as in Niger.

Hydrologic budget analyses could also be used to determine the probability of mid-season droughts. Where such droughts occur frequently, consideration might be given to the use of either spreading types, semi-erect types such as "Mouride" or, if the optimal cycle length is long enough, early erect types with DLS. In many semi-arid environments varietal intercrops with contrasting types of cultivars may be useful.

\section{TRIAL PLANNING}

A key step in developing cultivars with enhanced adaptation to drought is to select for high average, stable yields in the TPZ. Initial field trials should be conducted with sole crop cowpeas grown on experiment stations throughout the TPZ. Separate trials should be conducted with sets of lines that have different cycle lengths and morphology. For example, one series of trials might be conducted with extremely extra-early (60-day cycle) erect lines, and another series with spreading 75-day cycle lines. Grain and hay yield should be determined for all entries, which will also provide the opportunity to calculate the apparent HI, a trait that may be useful in selection. A subset of the most effective lines would be chosen based on their performance in the experiment station trials. This small subset of lines would then be evaluated in farmer-managed, on-farm trials in the TPZ that include evaluations of grain quality by local people. Those lines that meet the needs of farmers and consumers, and that have high average, stable yields of grain, southern peas, and hay (depending on farmer and consumer needs and the type of cultivar being tested) would be candidates for release as cultivars.

\section{WATER STRESS MANAGEMENT AND CHARACTERIZATION}

Rainfall and potential evapotranspiration data, and in some cases pre-season and post-season soil moisture data should be taken at all trial sites so that hydrologic budget analyses can be performed to help in interpreting the data on plant performance. Ideally these analyses would be conducted for both the experiment station and on-farm trials.

\section{PHENOTYPING TRAITS}

With respect to drought adaptation, in addition to careful consideration of optimal phenology and morphology, it should be ensured that the available vegetative-stage drought resistance is present. The seedling screen involving a shallow soil layer in a box (Singh and Matsui, 2002) can be used to screen parents and, if necessary, segregating generations. Singh and Matsui (2002) and Muchero et al. (2008) have described some variation in this trait but it is not known whether it is worth pursuing, since some cowpea cultivars already have very strong resistance to vegetative-stage drought.

The robustness of cowpeas under hot dry soil conditions during the seedling and vegetative-stages could be enhanced considerably by incorporating the resistance to ashy stem blight ( $M$. phaseolina) that recently has been discovered (Ehlers, unpublished observations). 
The DLS trait may be useful, in some environments for enhancing resistance to mid-season droughts and/or enhancing hay quality. DLS can be incorporated using field nurseries that are naturally infested with F. solani f. sp. phaseoli. This organism may already be present in fields where cowpeas have been grown for several years, even where rotations have been practiced. Selection for DLS has been effective with lines in advanced generations (Ismail et al., 2000) but may not be effective with single plants. When selecting plants with DLS, only those with high pod set should be chosen because plants with little or no pod set, such as the occasional sterile plant, exhibit a false form of DLS that has no agronomic value.

In addition, high priority in the breeding program must be given to incorporating resistances to seed-borne diseases since these diseases are usually major problems confronting cowpea production. Genetic resistances are available in most cases but have not yet been incorporated into some current cultivars.

To reduce the need for applying pesticides, effort should be devoted to incorporating resistances to important insect pests, such as flower thrip, hairy caterpillar, pod borer, and various pod bugs that occur in the Sahelian and Sudanian Savanna zones. For some of these insects, strong sources of genetic resistance are not yet available.

Consideration should also be given to traits that benefit subsequent cereal crops grown in rotation, providing that these traits are relatively easy to incorporate. For example, in the Sahelian zone effort should be devoted to enhancing the resistance of cowpea cultivars to the nematode $S$. cavenessi both to improve cowpea performance in dry, infertile soils and to make it a more effective rotation crop with pearl millet, sorghum, and peanut which are susceptible to this nematode.

\section{REFERENCES}

Bates, L. M., and Hall, A. E. (1981). Stomatal closure with soil water depletion not associated with changes in bulk leaf water status. Oecologia 50, 62-65.

Cisse, N., Ndiaye, M., Thiaw, S., and Hall, A. E. (1995). Registration of 'Mouride' cowpea. Crop Sci. 35, 1215-1216.

Cisse, N., Ndiaye, M., Thiaw, S., and Hall, A. E. (1997). Registration of 'Melakh' cowpea. Crop Sci. 37, 1978.

Condon, A. G., and Hall, A. E. (1997). "Adaptation to diverse environments: variation in water-use efficiency within crop species," in Ecology in Agriculture, Physiological Ecology Series, ed. L. E. Jackson (San Diego, CA: Academic Press), 79-116.

Dancette, C., and Hall, A. E. (1979). "Agroclimatology applied to water management in the Sudanian and Sahelian zones of Africa," in Agriculture in Semi-Arid Environments,

\section{CONCLUSION}

Due to the small number of active cowpea breeding programs in the world in relation to the large numbers of farmers growing this crop, the major effort in cowpea breeding must be on downstream programs that are devoted to cultivar development. These programs must focus on high priority constraints that can be solved at this time, such as by incorporating the resistances that are available to some of the major pests and diseases occurring in the TPZs.

With respect to drought adaptation, key factors involve achieving optimal time of flowering and cycle length, and appropriate morphology as they relate to the hydrologic budgets of TPZs and the different types of cultivars needed in relation to their utilization for dry grain, hay, and fresh pea production. The strong resistance to vegetative-stage drought that is available should be incorporated. The extreme ability of extra-early erect cowpea cultivars to escape terminal drought should be exploited in zones with very short rainfall seasons. In zones with the possibility of limited rainfall in the middle of the growing season, resistance to mid-season drought and the delayed-leaf-senescence trait can be valuable. Effective performance testing through field trials on experiment stations and by farmers is essential in breeding to enhance adaptation to drought and to encourage adoption of cultivars by farmers.

With respect to upstream research, emphasis should be given to developing MAS schemes for resistances to major pests and diseases. Cowpea breeders typically have to incorporate several resistances; methods that make possible the pyramiding of resistance genes would enhance the efficiency of their programs. A genetic linkage map that provides a basis for beginning this work has been developed (Ouédraogo et al., 2002). The strong vegetative-stage drought resistance of cowpeas might be studied with the objective of transferring it to other crop species using transgenic methods.

well-watered and dry field conditions. Field Crops Res. 15, 229-244.

Elowad, H. O. A., Hall, A. E., and Jarrell, W. M. (1987). Comparisons of ureide and acetylene reduction methods for estimating biological nitrogen fixation by glasshouse-grown cowpea. Field Crops Res. 15, 215-227.

Gwathmey, C. O., and Hall, A. E. (1992). Adaptation to midseason drought of cowpea genotypes with contrasting senescence traits. Crop Sci. 32, 773-778.

Gwathmey, C. O., Hall, A. E., and Madore, M. A. (1992a). Adaptive attributes of cowpea genotypes with delayed monocarpic leaf senescence. Crop Sci. 32, 765-772.

Gwathmey, C. O., Hall, A. E., and Madore, M. A. (1992b). Pod removal effects on cowpea genotypes contrasting in monocarpic senescence traits. Crop Sci. 32, 1003-1009.

Hall, A. E. (1992). Plant Breeding Reviews, Vol. 10, Chap. 5. New York: John Wiley and Sons, 129-168.
Hall, A. E. (1999). "Cowpea," in Crop Yield Physiology and Processes, eds D. L. Smith and C. Hamel (Berlin: Springer-Verlag), 355-373.

Hall, A. E. (2004a). Breeding for adaptation to drought and heat in cowpea. Eur. J. Agron. 21, 447-454.

Hall, A. E. (2004b). "Comparative ecophysiology of cowpea, common bean and peanut," in Physiology and Biotechnology Integration for Plant Breeding, eds H. Nguyen and A. Blum (New York: Marcel Dekker Inc.), 271-325.

Hall, A. E., and Dancette, C. (1978). Analysis of fallow-farming systems in semi-arid Africa using a model to simulate the hydrologic budget. Agron. J. 70, 816-823.

Hall, A. E., and Frate, C. A. (1996). Blackeye Bean Production in California. CA: University of California Division of Agricultural Science Publications 21518, 23. 
Hall, A. E., Ismail, A. M., Ehlers, J. D., Marfo, K. O., Cisse, N., Thiaw, S., and Close, T. J. (2002). "Breeding cowpea for tolerance to temperature extremes and adaptation to drought," in Challenges and Opportunities for Enhancing Sustainable Cowpea Production, eds C. A. Fatokun, S. A. Tarawali, B. B. Singh, P. M. Kormawa, and M. Tamò (Ibadan: IITA), 14-21.

Hall, A. E., and Patel, P. N. (1985). "Breeding for resistance to drought and heat," in Cowpea Research, Production, and Utilization, eds S. R. Singh and K. O. Rachie (New York: John Wiley and Sons), 137-151.

Hall, A. E., Richards, R. A., Condon, A. G., Wright, G. C., and Farquhar, G. D. (1994a). Plant Breeding Reviews, Vol. 12, Chap. 4. New York: John Wiley and Sons, 81-113.

Hall, A. E., Thiaw, S., and Krieg, D. R. (1994b). Consistency of genotypic ranking for carbon isotope discrimination by cowpea grown in tropical and subtropical zones. Field Crops Res. 36, 125-131.

Hall, A. E., Thiaw, S., Ismail, A. M., and Ehlers, J. D. (1997). "Water-use efficiency and drought adaptation of cowpea," in Advances in Cowpea Research, eds B. B. Singh, D. R. Mohan Raj, K. E. Dashiell, and L. E. N. Jackai (Ibadan: IITA), 87-98.

Ismail, A. M., and Hall, A. E. (1992). Correlation between water-use efficiency and carbon isotope discrimination in diverse cowpea genotypes and isogenic lines. Crop Sci. 32, 7-12.

Ismail, A. M., and Hall, A. E. (1998). Positive and potential negative effects of heat-tolerance genes in cowpea lines. Crop Sci. 38, 381-390.

Ismail, A. M., and Hall, A. E. (2000). Semidwarf and standardheight cowpea responses to row spacing in different environments. Crop Sci. 40, 1618-1623.

Ismail, A. M., Hall, A. E., and Ehlers, J. D. (2000). Delayed-leaf-senescence and heat-tolerance traits mainly are independently expressed in cowpea. Crop Sci. 40,1049-1055.

Khalfaoui, J.-L. B., and Havard, M. (1993). Screening peanut cultivars in the field for root growth: a test by herbicide injection in the soil. Field Crops Res. 32, 173-179.

Mligo, J. K., and Singh, B. B. (2007). Registration of 'Vuli-1' cowpea. Crop Sci. 47, 437-438.

Muchero, W., Ehlers, J. D., and Roberts, P. A. (2008). Seedling stage droughtinduced phenotypes and droughtresponsive genes in diverse cowpea genotypes. Crop Sci. 48, 541-552.

Ouédraogo, J. T., Gowda, B. S., Jean, M., Close, T. J., Ehlers, J. D., Hall, A. E., Gillaspie, A. G., Roberts, P. A., Ismail, A. M., Bruening, G., Gepts, P., Timko, M. P., and Belzile, F. J. (2002). An improved genetic linkage map for cowpea (Vigna unguiculata L) combining AFLP, RFLP, RAPD, biochemical markers, and biological resistance traits. Genome 45, 175-188.

Padi, F. K., Denwar, N. N., Kaleem, F. Z., Salifu, A. B., Clottey, V. A., Kombiok, J., Haruna, M., Hall, A. E., and Marfo, K. O. (2004a). Registration of 'Apagbaala' cowpea. Crop Sci. 44, 1486.

Padi, F. K., Denwar, N. N., Kaleem, F. Z., Salifu, A. B., Clottey, V. A., Kombiok, J., Haruna, M., Hall, A. E., and Marfo, K. O. (2004b). Registration of 'Marfo-Tuya' cowpea. Crop Sci. 44, 1486-1487.

Petrie, C. L., and Hall, A. E. (1992a). Water relations in cowpea and pearl millet under soil water deficits: I. Contrasting leaf water relations. Aust. J. Plant Physiol. 19, 577-589.
Petrie, C. L., and Hall, A. E. (1992b). Water relations in cowpea and pearl millet under soil water deficits: II Water use and root distribution. Aust. J. Plant Physiol. 19, 591-600.

Petrie, C. L., and Hall, A. E. (1992c). Water relations in cowpea and pearl millet under soil water deficits: III. Extent of predawn equilibrium in leaf water potential. Aust. J. Plant Physiol. 19, 601-609.

Robertson, B. M., Hall, A. E., and Foster, K. W. (1985). A field technique for screening for genotypic differences in root growth. Crop Sci. 25, 1084-1090.

Sène, D. (1966). Inventaire des principales variétés de niébé (Vigna unguiculata Walpers) cultivées au Senegal. Agron. Trop. 21, 927-933.

Shackel, K. A., and Hall, A. E. (1979). Reversible leaflet movements in relation to drought adaptation of cowpeas, Vigna unguiculata (L) Walp. Aust. J. Plant Physiol. 6, 265-276.

Shackel, K. A., and Hall, A. E. (1983). Comparison of water relations and osmotic adjustment in sorghum and cowpea under field conditions. Aust. J. Plant Physiol. 10, 423-435.

Singh, B. B., Ehlers, J. D., Sharma B., and Freire Filho, F. R. (2002). "Recent progress in cowpea breeding," in Challenges and Opportunities for Enhancing Sustainable Cowpea Production, eds C. A. Fatokun, S. S. Tarawali, B. B. Singh, P. M. Kormawa, and M. Tamò (Ibadan: IITA), 22-40.

Singh, B. B., and Matsui, T. (2002). "Cowpea varieties for drought tolerance," in Challenges and Opportunities for Enhancing Sustainable Cowpea Production, eds C. A. Fatokun, S. A. Tarawali, B. B. Singh, P. M. Kormawa, and M. Tamò (Ibadan: IITA), 287-300.
Thiaw, S., and Hall, A. E. (2004). Comparison of selection for either leafelectrolyte-leakage or pod set in enhancing heat tolerance and grain yield of cowpea. Field Crops Res. 86, 239-253.

Thiaw, S., Hall, A. E., and Parker, D. R. (1993). Varietal intercropping and the yields and stability of cowpea production in semiarid Senegal. Field Crops Res. 33, 217-233.

Timko, M. P., Ehlers, J. D., and Roberts, P. A. (2007). “Cowpea," in Genome Mapping and Molecular Breeding in Plants: Pulses, Sugar and Tuber Crops, Vol. 3, ed. C. Kole (New York: Springer-Verlag), 49-63.

Turk, K. J., Hall, A. E., and Asbell, C. W. (1980). Drought adaptation of cowpea. I. Influence of drought on seed yield. Agron. J. 72, 413-420.

Conflict of Interest Statement: The author declares that the research was conducted in the absence of any commercial or financial relationships that could be construed as a potential conflict of interest.

Received: 12 March 2012; accepted: 03 May 2012; published online: 25 May 2012.

Citation: Hall AE (2012) Phenotyping cowpeas for adaptation to drought. Front. Physio. 3:155. doi: 10.3389/fphys.2012.00155

This article was submitted to Frontiers in Plant Physiology, a specialty of Frontiers in Physiology.

Copyright ( $(2012$ Hall. This is an openaccess article distributed under the terms of the Creative Commons Attribution Non Commercial License, which permits non-commercial use, distribution, and reproduction in other forums, provided the original authors and source are credited. 